$\xi=-1$

\title{
Operational dashboard: Accelerator for shop floor workers
}

\author{
E. M. M. Yusof ${ }^{1 *}$, M. S. Othman ${ }^{2}$, A. R. M. Yusof ${ }^{3}$ \\ ${ }^{1}$ Universiti Kuala Lumpur, Malaysian Institute of Industrial Technology, Persiaran Sinaran Ilmu, \\ 81750 Bandar Seri Alam, Johor Bahru, Johor, Malaysia. \\ ${ }^{2}$ Centre for Information and Communication Technology, Universiti Teknologi Malaysia, 81310 UTM Johor Bahru, Johor, Malaysia. \\ ${ }^{3}$ Institute of Occidental Studies, University Kebangsaan Malaysia, 43600 Bangi, Malaysia. \\ *Corresponding authorE-mail: erniemazuin@unikl.edu.my
}

\begin{abstract}
Executing job tasks faster is essential for employees working in the operation section of manufacturing organizations nowadays in order to achieve target profit and gain customer satisfaction. Thus, having a tool to assist them in performing their work faster is necessary. Existing IT system does exist to supply the data they need. However, the entire process is invisible because there is no real-time information available. This causes delay in decisions that they need to make for the operation of the section. To address these issues, this paper presents the Operational Dashboard (OD) for the workers in the operation section of the manufacturing firm. The workers' needs were first identified to ensure that a right dashboard is being constructed, which is the OD. The OD system was then implemented in the manufacturing firm following the users' requirements. The implementation of the OD had shown its effectiveness in shortening the time of the data analysis by the employees in the section. This eventually led to improvement in the decision making process in such a way that the process was done faster as compared to the previous practice.
\end{abstract}

Keywords: Operational Dashboar, Manufacturing Operation; Visualization.

\section{Introduction}

The manufacturing sector experienced a fast growth globally in the 21 st century, especially in the electronic and electrical segment [1]. It has also contributed to $7.3 \%$ of the Malaysian economy in 2014 [1]. Thus, in order to stay competitive in the market, the manufacturing organizations must maintain their target profit and at the same time increase customer's satisfaction [2]. In order to achieve them, a quick and effective decision to solve problems related to the operation of the manufacturing organization is very much needed by the employees especially in the production or shop floor section [2]. The employees require faster and accessible information related to their operations or shop floor activities. Information Technology (IT) solution systems in manufacturing do exist in order to support the operation of the organization, such as Enterprise Resource Planning (ERP) or Supply Chain Management (SCM) Software [2]. However, these systems do not focus on the core operation or shop floor status of the manufacturing organization itself [3]. They emphasized more on the enterprise level only. Other than that, the conventional approach to display the information needed by the shop floor operation like the notice board seemed to be slow since it is done manually by the workers [4]. For example, employees who are working in the production section organization need to know the status of the product they build whether it has been completed or not [5]. However, the problem that exists in the operation section is, the entire process is invisible because there is no real-time information available. In addition, issues like limited information visualization on the overall enterprise processes are the problem faced in many manufacturing organizations [6].
Therefore in this paper, we would like to propose an Operational Dashboard (OD) concept that is able to get the information required by the operation employees of the manufacturing organization in an understandable and real-time manners. The OD created will shorten the time of operation employees in performing their work. The case study is done in a manufacturing based company that produces electronics products. The data is taken from a Microsoft Excel file generated by the IT application in the company. This paper is organized as follows: First, we outline the concept of OD and justify our reason to choose the OD in section 2. Next, we explain our step to identify the users' need in section 3 that provides the basis for the dashboard implementation in section 4 . Section 5 will discuss on the results obtained upon the implementation of the OD. Finally in section 6, we conclude our work.

\section{Operational Dashboard}

A dashboard can be likened to the dashboard of a vehicle where it consists of a steering wheel, speedometer, seat belt warning light, fuel gauge, and other indications [7]. Vehicle's dashboard is very important to show the operational status of many types of vehicle like cars, vans, lorries and buses. In the context of IT, Yusof and Othman defined dashboard as an information that is represented visually to aid the decision making process of a business segment by giving the intended users a clearer guidance to make an accurate and fast decision [8]. This information is retrieved by the transformation of the existing business data. A dashboard is one of the Business Intelligence (BI) tools that is focusing on the visual representation of data that shows the performance of organization's operation [6]. The dashboard development process consid- 
ers to integrate with the existing manufacturing systems, as well as having the web and portal for the business process.

There are various types of dashboard that served different purposes as depicted in Table 1 [9].

Table 1: Dashboard Types

\begin{tabular}{|c|c|c|}
\hline $\begin{array}{l}\text { Dashboard } \\
\text { Type }\end{array}$ & $\begin{array}{l}\text { Intended } \\
\text { Users } \\
\end{array}$ & Purpose \\
\hline $\begin{array}{l}\text { Strategic } \\
\text { Dashboards }\end{array}$ & $\begin{array}{l}\text { Executives and } \\
\text { Managers }\end{array}$ & $\begin{array}{l}\text { 1. To provide visual information in a } \\
\text { larger scale like facilitating } \\
\text { improvement in possible areas, } \\
\text { monitoring the health of organization } \\
\text { to support goals and objectives within } \\
\text { an organization. } \\
\text { 2. No critical need for interactive } \\
\text { features } \\
\text { 3. Departments that are using strategic } \\
\text { dashboard: Sales, Human } \\
\text { Resources, Manufacturing, and } \\
\text { Services. }\end{array}$ \\
\hline $\begin{array}{l}\text { Analytical } \\
\text { Dashboards }\end{array}$ & $\begin{array}{l}\text { Analyst and } \\
\text { Management } \\
\text { Personnel }\end{array}$ & $\begin{array}{l}\text { 1. To provide visual information to } \\
\text { better understand the historical, } \\
\text { present and future data and trends, } \\
\text { view and make comparisons and do } \\
\text { needed adjustments. } \\
\text { 2. Interactive features are necessary. } \\
\text { 3. Main purpose is to get real-time } \\
\text { information to determine the working } \\
\text { status of processes, identify patterns } \\
\text { and opportunities of data and align } \\
\text { strategic objectives with performance } \\
\text { efforts. }\end{array}$ \\
\hline $\begin{array}{l}\text { Operational } \\
\text { Dashboards }\end{array}$ & $\begin{array}{l}\text { Operation } \\
\text { Personnel }\end{array}$ & $\begin{array}{l}\text { 1. To provide visual information to } \\
\text { concentrate on performance } \\
\text { monitoring and measurements and } \\
\text { monitor the efficiency and } \\
\text { effectiveness of organization. } \\
\text { 2. Information displayed must be } \\
\text { updated frequently and relevant to the } \\
\text { users' need. } \\
\text { 3. Main purpose is to improve } \\
\text { understanding of performance, induce } \\
\text { better focus and alignment, and } \\
\text { facilitate faster and better decision } \\
\text { making. }\end{array}$ \\
\hline
\end{tabular}

In summary, the strategic dashboards are used more in the management level of the organization where improvement will be done based on the monitored health of the organization in a larger scale. This is to accomplish certain goals and objectives of the organization. On the other hand, analytical dashboards are also used by the management personnel executives to make comparison between the past, present and future trends and do adjustment where necessary. This is to ensure the organization's objectives are always aligned with the performance efforts. Whereas the ODs are more suitable to be used by the operation personnel of the organization. Moreover, the information displayed by the OD must be in real-time so that a fast and better decision making process can be achieved.

\section{Identify Users' Need}

The first step to do in order to develop our OD is to identify the users' need [10]. We need to know on the details that users need to measure. One of the methods to achieve this is to conduct survey with the employees of the firm, through interview [11]. Therefore, interview sessions had been conducted with the employees of the manufacturing firm, particularly the ones who are working in the operation section. Based on the interview session, in order to for the employees of the operation section of the manufacturing firm carry out their job tasks faster, the followings were required:

1. Quick access and visibility to completed and uncompleted orders of the orders data.

2. Immediate action and decision to be made on uncompleted orders of the month so that problems will be solved quickly.
Based on the requirements listed by the employees, OD is seen as the most suitable type of dashboard to be used in that manufacturing firm. It served the purpose of displaying a real-time data to make a fast and effective decision in the operation section of the manufacturing organization. Other than that, it could also help the employees in that section to perform their job tasks faster.

\section{Dashboard Implementation}

A dashboard system has been designed. Figure 1 illustrated the dashboard's main page. In the dashboard main page module, the users can view the status of the current month's order. This means that the status is displayed in real time. The status is of the materials' preparation and the build, whether they have been completed or not. The users can download the report to examine the orders and know the exact problem that the process is facing for incomplete orders. This main page is accessible by all staffs involved in the operation section of the manufacturing firm. The characteristics of the dashboard that are shown here are the real-time status of the orders and display the shop floor status, i.e. the operational data.

\section{$5 \quad$ Results and Findings}

From the interview sessions conducted with the staffs from the operation section of the Manufacturing firm, their feedback was obtained. Their feedback was gathered on the amount of time saved by using the dashboard as compared to the previous manual method they were using. The type of data they were analysing is the orders data for one month period. Brief details of the interview session and the summary of their feedback are tabulated in Table 2 and Table 3 , respectively.

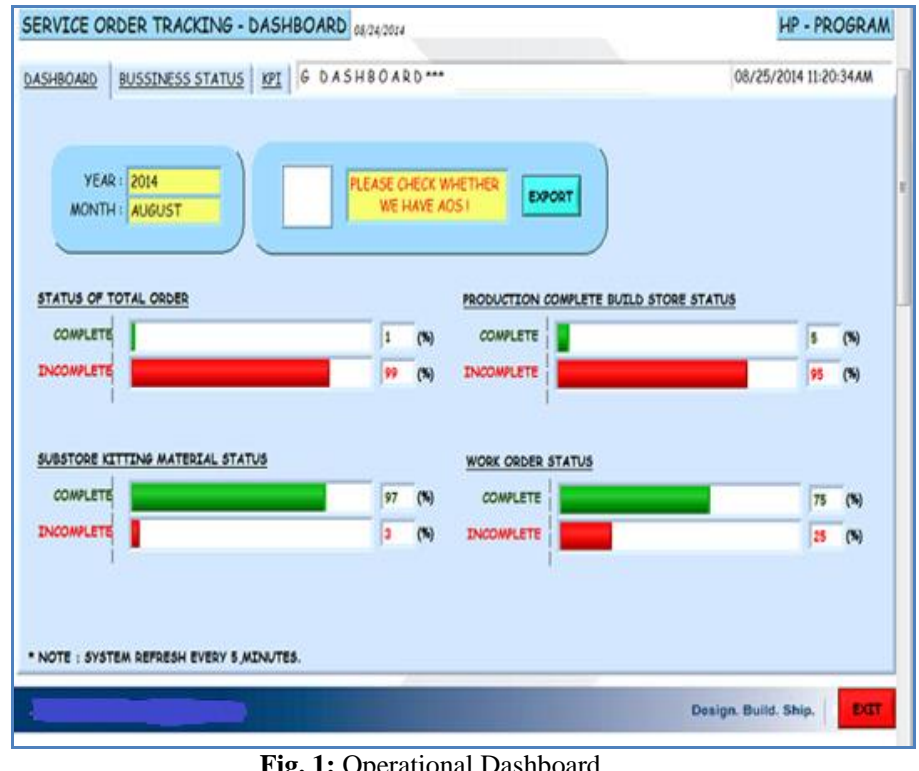

Meanwhile, the staffs' feedback from Table 2 is reflected in Figure 4 . The graph in the figure shows that there is a difference in the amount of time the staffs had taken to analyze the order data before and after the implementation of the dashboard. The amount of time the staffs spent on analysing the order data has seen a reduction. With lesser time of analysing the order management data, solving problems of uncompleted orders could now be done immediately as compared to the previous situation before the dashboard implementation. This means that the decision support process has improved with the dashboard. 
Table 2: Interview Information

\begin{tabular}{|l|l|}
\hline $\begin{array}{l}\text { Number of In- } \\
\text { terviewees }\end{array}$ & 5 \\
\hline $\begin{array}{l}\text { Type of Feed- } \\
\text { back Gathered }\end{array}$ & $\begin{array}{l}\text { How much time is saved by using the OD, com- } \\
\text { pared to previous manual method }\end{array}$ \\
\hline Type of Data & $\begin{array}{l}\text { Orders Data from existing tracking system's report } \\
\text { in Microsoft Excel }\end{array}$ \\
\hline Period of Data & 1 month \\
\hline Length of Data & 600 rows, 20 columns \\
\hline
\end{tabular}

Table 3: Respondents' Feedback on the Operational Dashboard from the Order Management of Service Build Section of the Manufacturing Firm

\begin{tabular}{|c|c|l|}
\hline $\begin{array}{c}\text { Staff Title } \\
\text { Supenior }\end{array}$ & $\begin{array}{c}\text { Unit } \\
\text { Produc- } \\
\text { tion }\end{array}$ & $\begin{array}{l}\text { Weekly analysis of the order data which } \\
\text { took 4 hours previously now had been re- } \\
\text { duced to 1 hour }\end{array}$ \\
\hline Leader & $\begin{array}{c}\text { Produc- } \\
\text { tion }\end{array}$ & $\begin{array}{l}\text { Daily analysis of uncompleted orders took } \\
15 \text { minutes as compared to before which } \\
\text { took nearly 1 hour }\end{array}$ \\
\hline Supervisor & Sub Store & $\begin{array}{l}\text { 2 hours wasted on analyzing the order data. } \\
\text { With the dashboard implemented, the anal- } \\
\text { ysis now took only 30 minutes }\end{array}$ \\
\hline Leader & Sub Store & $\begin{array}{l}\text { Daily analysis for unprepared orders took } \\
15 \text { minutes as compared to the previous } \\
\text { which took nearly 1 hour }\end{array}$ \\
\hline
\end{tabular}

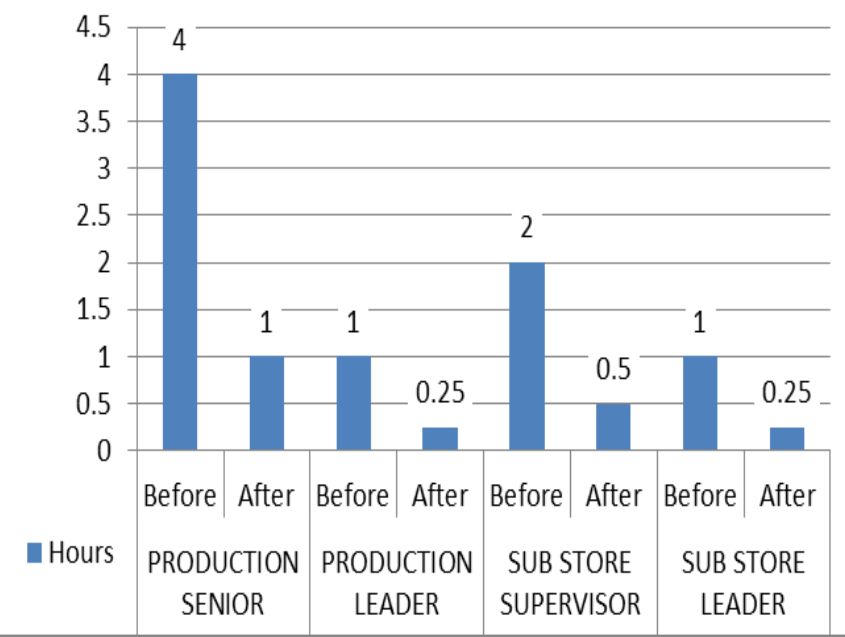

Fig. 4: Comparison in Time Saved when Analysing Data: Before and After the OD Implementation

\section{Conclusion}

In this article, from all the information obtained, the solution to the current problems faced by the area of the manufacturing organization had been identified by constructing an OD system. The OD had shown its effectiveness in shortening the time of the data analysis by the employees in the operation section of the manufacturing firm. This eventually leads to improvement in the decision making process in such a way that the process is done faster as compared to the previous practice.

This research contributes in the use of OD in supporting the decision making processes of the operation section of the manufacturing organization, in the sense that the visual representation of data as characterized by the OD system may help the employees examine their data faster. This is so because the abundance of data which is previously so time-consuming to analyze, will be turned into needed information by the OD. The OD designed has to be in real-time and include historical and future data (if possible). With those characteristics of an $\mathrm{OD}$, it has helped the employees in the operation section of the manufacturing company to shorten their time in analysing the huge amount of customer's order data. This has also helped them to decide fast in problems that need escalation for the uncompleted orders.

\section{References}

[1] Hooi, L. W. Organizational Justice and Citizenship Behaviour in Malaysia. Springer (2016). ISBN: 978-981-10 0030-0.

[2] Laudon, K. C., Laudon, J. P. and Elragal, A. A. Management Information Systems - Managing the Digital Firm. Edition Arab World. Pearson Education Limited (2013). ISBN: 978-1-40827160-5

[3] Bracht, U., Hackenberg. W and Bierwirth, T. A Monitoring Approach for the Operative CKD Logistics - Increased Efficiency Through Optimized Flows of Information by Means of Digital Factory Tools. Werkstattstechnik (2011), 101 (3), pp. 122-127.

[4] Grögera, C., Mark, H., Hahna, F., Mitschanga, B. and Westkämpera, H. The Operational Process Dashboard for Manufacturing. Forty Sixth CIRP Conference on Manufacturing Systems (2013). Elsevier/Science Direct, 205-210.

[5] Yusof, E. M. M., Othman, M. S., Omar, Y. and Yusof, A. R. M. The Study on the Application of Business Intelligence in Manufacturing: A Review. International Journal of Computer Science Issues (2013), 10(1), 317-324

[6] Nunes, B., Bennett, D. and Shaw, D. Building a Competitive Advantage Through Sustainable Operations Strategy. 22nd International Conference on Management of Technology (2013), 1-16.

[7] Yusof, E. M. M. Enhanced Dashboard for Manufacturing Order Management Decision Making. Master Thesis (2014). Universiti Teknologi Malaysia.

[8] Yusof, E. M. M. and Othman, M. S. A Review on the Dashboard Characteristics for Manufacturing Organizations. Journal of Information Systems Research and Innovation (2012), (2), 28-34.

[9] Lafler, K. P. Building a Better Dashboard Using Base SAS® Software. Proceedings for PharmaSUG (2016), AD12.

[10] Aanderud, T. and Homes, M. Admins Need a Dashboard, Too. Dashboards with SAS $®$ Visual Analytics, SAS® North Carolina State University (2014), Paper 1247.

[11] Khalifa, M. and Khalid, P. Developing Strategic Health Care Key Performance Indicators: A Case Study on a Tertiary Care Hospital. PhD. The 5th International Conference on Current and Future Trends of Information and Communication Technologies in Healthcare (2015), 459 - 466

[12] Copani, G. and Rosa, P. DEMAT: Sustainability Assessment of New Flexibility-Oriented Business Models in the Machine Tools Industry. International Journal of Computer Integrated Manufacturing (2015), Volume 28, Issue 4.

[13] Mousaa, A. H., Shiratuddinb, N. and Bakar, M. S. A. Process Oriented Data Virtualization Design Model for Business Processes Evaluation (PODVDM) Research in Progress. Jurnal Teknologi, UTM (2015), 72:4, 121-125.

[14] Henning, B. and Julian, E. From Data Warehouses to Analytica Atoms - The Internet of Things as a Centrifugal Force in Business Intelligence and Analytics. Twenty-Fourth European Conference on Information Systems (2016), 1-18.

[15] Mandal, S. Towards a Relational Framework for Supply Chain Analytics. International Journal of Applied Engineering Research (2016), Volume 11, Number 7, 4838-4843.

[16] Moniruzzaman, M., Kurnia, S., Parkes, A. and Maynard, S. B. Business Intelligence and Supply Chain Agility. (2015). 1-16.

[17] Gröger, C. and Stach, C. The Mobile Manufacturing Dashboard Proceedings of the 2014 IEEE International Conference on Pervasive Computing and Communications Workshops (2014), 138-140.

[18] Kumar, H. Production Surveillance Dashboards in Upstream Industry. Wipro Technologies (2013). White Paper.

[19] Mavatoor, D. Flow Manufacturing: How to Achieve Superior Customer Response. Cognizant 20-20 Insights (2013). White Paper. 